\title{
Analisis Yuridis Terhadap Perbuatan Mark-up Oleh Panitia Pengadaan Barang Dan Jasa Dalam Proyek Pemerintah
}

\section{Juridical Analysis of Mark-up Actions by the Procurement Committee for Goods and Services in Government Projects}

\author{
Rika Susilawaty, Triono Eddy \& Alpi Sahari \\ Program Magister Ilmu Hukum, Universitas Muhammadiyah Sumatera Utara, Indonesia
}

Diterima: Juni 2020; Disetujui: Agustus 2020; Dipublish: Agustus 2020

*Email: rikasusilawaty39@gmail.com

\begin{abstract}
Abstrak
Pengaruh perkembangan lingkungan strategis maupun pengaruh aspek motivasi pelaku, aspek kebijakan atau aspek penegakan hukum, telah mempengaruhi peningkatan Penyelundupan yang terjadi, baik Penyelundupan impor maupun Penyelundupan ekspor, meningkatnya kasus Penyelundupan khususnya Penyelundupan impor telah menimbulkan berbagai dampak, terutama menurunya kemampuan daya saing produksi dalam negeri di pasaran yang akirnya akan berpengaruh pula terhadap perbaikan pereonomian nasional. Penelitian yang dilakukan adalah penelitian deskriptif dengan metode pendekatan hukum normatif (yuridis normatif) dilakukan dengan cara studi kepustakaan. Alat pengumpulan data yang digunakan dalam penelitian ini adalah data berupa studi dokumen dan penelusuran kepustakaan. yang menjadi pisau analisis dalam penelitian ini ialah teori kepastian hukum, teori pertanggungjawaban pidana, dan teori kebijakan hukum pidana. Sanksi yangyang diberikan Majelis hakim terhadap terdakwa tidak mengambarkan keadilan serta ketertiban dimasyarakat, dikarenakan hukuman yang cenderung ringan serta tidak memberian efek jera terhadap pelaku tindak pidana korupsi. Upaya penanggulangan kejahatan dengan hukum pidana (sarana penal) dan lebih menitikberatkan pada sifat "Represive" (penindasan / pemberantasan / penumpasa) setelah kejahatan atau tindak pidana terjadi.
\end{abstract}

Kata Kunci: Mark-Up, Tindak Pidana, Penaggulangan

\begin{abstract}
The influence of the development of the strategic environment as well as the influence of the actors' motivational aspects, policy aspects or aspects of law enforcement, has influenced the increase in smuggling, both smuggling imports and export smuggling, increasing cases of smuggling, particularly smuggling of imports, has caused various impacts, especially the decline in the competitiveness of domestic production in the market which will ultimately also affect the improvement of the national economy. The research conducted is a descriptive study with a normative legal approach (normative juridical) conducted by means of literature study. Data collection tools used in this study are data in the form of document studies and literature searches. which become the knife of analysis in this study are theories of legal certainty, theories of criminal liability, and theories of criminal law policy. Sanctions given by the Panel of Judges against the defendant do not describe justice and order in the community, because the sentence tends to be mild and does not give a deterrent effect on the perpetrators of corruption. Efforts to deal with crime with criminal law (a means of punishment) and more emphasis on the nature of "Represive" (repression / eradication / suppression) after a crime or crime occurred.
\end{abstract}

Keywords: Mark-Up, Criminal Acts, Countermeasures

How to Cite: Susilawaty, R., Eddy, T. \& Sahari, A. (2020). Analisis Yuridis Terhadap Perbuatan Mark-up Oleh Panitia Pengadaan Barang Dan Jasa Dalam Proyek Pemerintah, Humaniora and Social Sciences (JEHSS). 3 (1): 91-96. 


\section{PENDAHULUAN}

Negara Indonesia sebagai negara hukum, akan tetapi dengan banyaknya permasalahan hukum yang belum dituntaskan terhadap pengadaan barang dan jasa. Jika kita lihat dari pengertian negara hukum adalah negara yang berdiri diatas hukum yang menjamin keadilan kepada warga sendirinya (Kusnardi, 1976).

Kemajuan suatu negara sangat ditentukan oleh kemampuan dan keberhasilannya dalam melaksanakan pembangunan. Pembangunan sebagai suatu proses perubahan yang direncanakan mencakup semua aspek kehidupan dalam bermasyarakat. Efektifitas dan keberhasilan dalam pembangunan terutama ditentukan oleh dua faktor, diantaranya faktor sumber daya manusia dan pembiayaan. Diantara dua faktor ini yag paling dominan muncul dalam masyarakat kita yaitu faktor sumber daya manusia. Fenomena yang dewasa ini belum menunjukan adanya satu sistem besar penegakan hukum (pemberantasan tipikor) yang dilaksanakan secara berkesinambungan dan terpadu diantara institusi penegakan hukum (Saymsuddin, 2011).

Mark-up dalam Pengadaan barang dan jasa salah satu peluang yang sangat besar untuk melakukan tindakan korupsi, peluang yang paling besar dapat melakukan tindakan korupsi yaitu pengadaan barang dan jasa, pengadaan Alkes pada rumah sakit dan bagian pendidikan, yang ketiga ini merupakan peluang yang sangat besar dapat melakukan korupsi dikarenakan pengurus didalamnya memiliki banyak struktural bahkan melakukan penunjukan atau menyeleksi pemenang tender terhadap pengadaan barang dan jasa sesuai dengan Perpres Nomor 70 Tahun 2012 tentang perubahan kedua atas perpres Nomor 54 Tahun 2010, tentang pengadaan barang dan jasa. Prinsipnya berada di perpros Nomor 54 tahun 2010 dalam pasal 5 "Pengadaan Barang/Jasa menerapkan prinsip-prinsip sebagai berikut: a. Efisien, b. Efektif, c. Transparan, d. Terbuka, e. Bersaing, f. adil/tidak diskriminatif, dan g. akuntabel."

Banyaknya berbagai kesalahan yang dilakukan panitia pengadaan barang dan jasa pemerintah, yang sering terjadi kesalahan yang mengakibatkan adanya tindakan pelanggaran hukum diantaranya kesalahan memandatariskan Surat Pembayaran Menerima (SPM), mark-up terhadap penyusunan HPS, dan sering terjadi tidak sesuai dengan barang yang telah ditentukan sesuai dengan kontrak-kontrak antara panitia dengan pengguna barang dan jasa. Panitia pengadaan barang dan jasa sering terjadi kekeliruan terhadap wewenang yang diberikan kepadanya sehingga banyaknya panitia pengadaan barang dan jasa perbuatannya mengakibatkan adanya akibat hukum dan merugikan keuangan negara.

Sementara ini terdapat banyak permasalahan dalam pelaksanaan program pengadaan barang dan jasa, seperti mark-up yang melampaui batas dan penegakan hukum yang dinilai bermasalah, maka hal ini menjadi sangat penting untuk dilakukan penelitian secara mendalam terhadap tindak pidana korupsi dalam pengadaan barang/jasa pemerintah khususnya dalam putusan PN No.11/PID.Tipikor/2013/PT.BKL. Dan berbagai penyebab atau cara pelaku melakukan kejahatan tindak pidana korupsi dalam rangka mark-up terhadap pengadaan barang dan jasa pemerintah. Setelah melakukan pelanggaran-pelanggaran dalam aturan hukum pengadaan barang dan jasa terkait dengan peraturan presiden republik Indonesia Nomor 70 Tahun 2012 tentang perubahan kedua atas peraturan presiden Nomor 54 Tahun 2010 tentang pengadaan barang dan jasa pemerintah, dan melanggar aturan hukum terkait dengan korupsi seperti Undang-undang Nomor 31 Tahun 1999 tentang pemberantasan tindak pidana korupsi.

Proses pengadaan barang dan jasa, salah satu tahapan yang krusial adalah penyusunan Harga Perkiraan Sendiri (HPS). Penyusunan HPS akan menentukan proses penawaran oleh penyedia barang dan jasa. Apabila HPS ditetapkan lebih mahal dari harga wajar maka akan menimbulkan potensi adanya kerugian Negara, akan tetapi apabila ditetapkan lebih rendah dari harga wajar berpotensi untuk terjadinya lelang gagal karena tidak ada penyedia barang yang berminat.

Harga Perkiraan Sendiri adalah perhitungan biaya atas pekerjaan barang/jasa sesuai dengan syarat-syarat yang ditentukan dalam dokumen pemilihan penyedia barang/jasa, dikalkulasikan secara keahlian dan berdasarkan data yang dapat dipertanggung-jawabkan. Pengadaan barang dan jasa yang baik diperlukan dalam menunjang berjalannya roda perekonomian bangsa. Berbagai 
temuan dan laporan dari aparat pemeriksa banyak menunjukkan penyimpangan dalam pengadaan barang dan jasa ini. Penyimpangan ini ditandai dengan banyaknya kasus penanganan tindak pidana mark-up yang ditangani oleh aparat hukum (Harahap, 2018; Lubis, dan Marlina, 2010; Sembiring, dan Ediwarman, 2011; Sihaloho, dkk., 2020).

Korupsi akan menyuburkan jenis kejahatan lain masyarakat seperti pencucian uang bahkan perampasan hak-hak orang lain dikarenakan sudah mempunyai uang yang berlebihan. Melalui korupsi, masyarakat biasa, pejabat negara, birokrat, bahkan aparat penegak hukum sekalipun dapat membengkokan hukum. Di Indonesia, korupsi sudah harus dilihat sebagai kejahatan yang luar biasa (extraordinary crime), bersifat, sistemik, serta sudah menjadi epidemik yang berdampak sangat luas (Girsang, 2012).

\section{METODE PENELITIAN}

Penelitian ini bersifat deskriptif analisis dengan spesifikasi penelitian hukum yuridis normatif untuk menemukan suatu aturan hukum, prinsip-prinsip hukum, maupun doktrin-doktrin hukum untuk menjawab permasalahan hukum yang dihadapi (Ediwarman, 2015). Sumber hukum dalam penelitian ini menacakup bahan hukum primer, bahan hukum sekunder dan bahan hukum tersier. Bahan hukum primer dalam penelitian ini mencakup Undang-Undang Nomor 31 tahun 1999 tentang tindak pidana korupsi jo undang-undang nomor 20 tahun 2001 jo pasal 55 kitab undang-undang hukum pidana serta putusan Pengadilan Negeri Medan yang telah berkekuatan hukum tetap No:11/PID.Tipikor/2013/PT.BKL.

Bahan hukum sekunder dalam penelitian ini berupa hasil-hasil seminar/pertemuan ilmiah, dokumen pribadi dan pendapat para kalangan pakar hukum sepanjang relevan dengan onjek penelitian ini. Metode pengumpulan data dilakukan melalui studi kepustakaan (library research) dengan studi dokumen. Data-data tersebut kemudoan dianalisis dengan metode kualitatif.

\section{HASIL DAN PEMBAHASAN}

\section{Analisis Putusan NOMOR: 11/PID.Tipikor/2013/PT.BKL}

Putusan hakim yang berkualitas adalah putusan yang didasarkan pada pertimbangan hukum yang sesuai dengan bukti serta fakta yang digali dalam sebuah persidangan serta putusan hakim juga harus sesuai dengan undang-undang dan keyakinan hakim yang tidak terpengaruh atau bebas dari segala intervensi atau tekanan baik dari eksekutif, legislatif maupun dari berbagai pihak serta selanjutnya dapat dipertanggungjawabkan secara profesional dan proporsional. Pertimbangan Majelis Hakim pada putusan No. 11/PID.Tipikor/2013/PT.BKL dapat dijadikan bahan analisis yuridis dalam penelitian ini.

Untuk menganalisis mark-up pengadaan barang dan jasa terhadap tindak pidana korupsi dalam Putusan Nomor 11/PID.Tipikor/2013/PT.BKL, dilakukan dengan penegakan norma-norma hukum yang berlaku tentang kerugian keuangan Negara yang berkaitan dengan tindak pidana korupsi. Asas legalitas melihat terkait dengan terpenuhi atau tidak terpenuhinya rumusan atau unsur-unsur pasal yang didakwakan kepada Terdakwa berdasarkan alat pembuktian dan keyakinan hakim dalam persidangan.

Berdasarkan dakwaan yang diajukan oleh Penuntut Umum Terhadap kasus posisi yang diuraikan diatas, oleh Jaksa Penuntut Umum (JPU) Terdakwanya telah terbukti secara sah dan meyakinakan melanggar perbuatan sebagaimana diatur dalam Pasal 2 ayat (1) Jo Pasal 18 UU Nomor 31 Tahun 1999 tentang Pemberantasan Tindak Pidana Korupsi yang telah diubah menjadi UU Nomor 20 Tahun 2001 tentang Pemberantasan Tindak Pidana Korupsi Jo Pasal 55 ayat (1) ke1 KUHP.

Adapun unsur-unsur Pasal Pasal 2 ayat (1) Jo Pasal 18 UU Nomor 31 Tahun 1999 tentang Pemberantasan Tindak Pidana Koupsi yang telah diubah menjadi UU Nomor 20 Tahun 2001 tentang Pemberantasan Tindak Pidana Korupsi Jo Pasal 55 ayat (1) ke-1 KUHP, yaitu: a. setiap orang; b. dengan tujuan menguntungkan diri sendiri atau orang lain suatu korporasi; c. menyalahgunakan kewenangan, kesempatan, atau sarana yang ada padanya karena jabatan atau kedudukan; d. yang dapat merugikan keuangan negara atau perekonomian negara; e. sebagai 
orang yang melakukan atau menyuruh melakukan, atau turut melakukan tindak pidana (Putusan PN. No.95/Pid.Sus.K/2013/Pn Medan).

Berdasarkan pemaparan dakwaan diatas serta penjelasan unsur-unsur pasal yang ada pada dakwaan tersebut maka penulis berpendapat dakwaan yang didakwa oleh jaksa penuntut umum kepada terdakwa sudah tepat sesuai dengan ketersediaan aturan hukum yang ada. Berdasarkan Pasal 55 ayat (1) ke-1 KUHP yang mengatur tentang penyertaan (deelneming), berbunyi :"Dipidana sebagai pelaku tindak pidana :orang yang melakukan, yang menyuruh melakukan, dan yang turut serta melakukan perbuatan" hal ini lah yang menjadi salah satu pertimbangan hakim dalam memberikan pidana ringan pada terdakwa.

Rumusan Pasal 55 (1) KUHP terdapat 3 (tiga) bentuk penyertaan yaitu pleger, doen pleger dan medepleger. Berdasarkan teori pertanggungjawaban pidana seseorang yang melakukan tindak pidana baru boleh dihukum apabila si pelaku sanggup mempertanggungjawabkan perbuatan yang telah diperbuatnya, masalah penanggungjawaban erat kaitannya dengan kesalahan, oleh karena adanya asas pertanggungjawaban yang menyatakan dengan tegas "Tidak dipidana tanpa ada kesalahan" untuk menentukan apakah seorang pelaku tindak pidana dapat dimintai pertanggungjawaban dalam hukum pidana, akan dilihat apakah orang tersebut pada saat melakukan tindak pidana mempunyai kesalahan.

Pelaku dalam tindak pidana korupsi secara generalis pelakunya merupakan subjek yang terpelajar serta berpendidikan, maka berdasarkan hal tersebut pelaku dalam tindak pidana korupsi dapat mempertanggunjawabkan perbuatannya dihadapan hukum pidana.

Dengan demikian pertimbangan hukum, hakim yang menjatuhkan pidana penjara bagi pelaku tindak pidana korupsi mark-up jika dilihat dari sudut pandang toeri pertanggungjawaban tersebut siapa yang berbuat dia yang bertanggungjawab sudah memiliki putusan yang tepat. Akan tetapi dalam putusan tersebut tidak ditemukan adanya hakim melakukan penjatuhan terhadap terdakwa untuk mengembalikan keuangan negara sehingga putusan tersebut tidak tepat sasaran. Sanksi yang yang diberikan Majelis hakim terhadap terdakwa tidak mengambambarkan keadilan serta ketertiban dimasyarakat, dikarenakan hukuman yang cenderung ringan serta tidak memberian efek jera terhadap pelaku tindak pidana korupsi.

Tujuan dilaksanakannya hukum adalah agar memberikan kepastian, kemanfaatan serta keadilan sebagaimana G. Radbruch, Einfuhrungindie Rechtswissenschaft, Stuttgart 1961 sebagaimana dikutip oleh Muhamad Erwin menyatakan, bahwa sesuatu yang dibuat pasti memiliki cita atau tujuan. Jadi hukum dibuat pun ada tujuannya.Tujuannya ini merupakan nilai yang ingin diwujudkan manusia. Tujuan hukum yang utama ada tiga, yaitu: keadilan untuk keseimbangan; kepastian untuk kecepatan; kemanfaatan untuk kebahagian (Erwin, 2012). Menciptakan atau menemukan hukum, terserah kepada anda untuk menamakannya, memberikan suatu gambaran di dalam pikiran tentang apa yang diperbuat seseorang dan mengapa ia berbuat (Pound, 1972).

Bagian penting dalam sistem pemidanaan adalah menetapkan suatu sanksi. Keadaannya akan memberikan arah dan pertimbangan mengenai apa yang seharusnya dijadikan sanksi dalam suatu tindak pidana untuk menegakkan berlakunya norma (Teguh Prasetyo; 2014). Beccaria berpendapat bahwa hukum harus mampu menjamin kebahagiaan yang sejati dari sebagian besar masyarakat (the greatest happiness of the great number) (Hamdan, 2010).

\section{Kebijakan Kriminal Terhadap Pertanggungjawaban Mark-Up oleh Panitia Pengadaan Barang dan Jasa}

Kebijakan Hukum Pidana (Penal Policy), Dalam hal mencapai tujuan tertentu hukum pidana tidak dapat bekerja sendiri, tetapi perlu melibatkan sarana-sarana lainnya yang mendukung, yakni tahapan kebijakan hukum pidana, dalam mengoperasionalkan hukum pidana, melalui tahap formulasi kebijakan legislatif atau pembuatan peraturan perundang-undangan, tahap perencanaan yang seharusnya memuat tentang hal-hal apa saja yang akan dilakukan, dalam mengadapi persoalan tertentu dibidang hukum pidana, dan kejahatan yang terjadi selalu berorientasi pada kebijakan penanggulangan kejahatan terpadu, sebagai upaya yang rasional guna pencapaian kesejahteraan masyarakat dan sekaligus perlindungan masyarakat (Muladi: 2009). 
Penggunaan hukum pidana dalam mengatur masyarakat (lewat peraturan perundangundangan) pada hakekatnya merupakan bagian dari suatu langkah kebijakan (policy). Operasionalisasi kebijakan hukum pidana dengan sarana penal (pidana) dapat dilakukan melalui proses yang terdiri atas tiga tahap (Baarda Nawawi; 2010), yakni tahap formulasi (kebijakan legislatif), tahap aplikasi (kebijakan yudikatif/yufdisial), dan eksekusi (kebijakan eksekutif/administratif).

Dilihat dari perspektif hukum pidana, maka kebijakan formulasi harus memperhatikan harmonisasi internal dengan sistem hukum pidana atau aturan pemidanaan umum yang berlaku saat ini. Tidaklah dapat dikatakan terjadi harmonisasi/sinkronisasi apabila kebijakan formulasi berada diluar sistem hukum pidana yang berlaku saat ini. Kebijakan formulasi merupakan tahapan yang paling stategis dari penal policy karena pada tahapan tersebut legislatif berwenang dalam hal menetapkan atau merumuskan perbuatan apa yang dapat dipidana yang berorientasi pada permasalahan pokok hukum pidana meliputi perbuatan yang bersifat melawan hukum, kesalahan, pertanggung jawaban pidana dan sanksi apa yang dapat dikenakan. Oleh karena itu, upaya penanggulangan kejahatan bukan hanya tugas aparat penegak hukum tetapi juga tugas aparat aparat legislatif Nawawi, 2010).

Dalam rangka menciptakan iklim pemerintahan yang baik (good governance), pemerintah melalui kebijakannya mengeluarkan Undang-Undang Nomor 20 Tahun 2001 tentang Pemberantasan Tindak Pidana Korupsi (selanjutnya disingkat dengan UU No. 20 Tahun 2001) bertujuan untuk mencegah praktek-praktek penyalahgunaan wewenang yang bisa dilakukan seseorang yang menduduki jabatan tertentu dalam pemerintahan dan merupakan pintu masuk terjadinya tindak pidana korupsi serta untuk menciptakan iklim pemerintahan yang baik. Terjadinya korupsi adalah karena adanya kekuasaan. Kekuasaan yang absolut cenderung koruptif, apalagi jika tidak ada transparansi, akuntabilitas dan check and balances (Sabrina Hidayat: 2018).

Penanganan tindak pidana dengan pendekatan perundang-undangan di kenal dengan upaya penal (represif) dengan pemberian sanksi barang siapa yang melakukan tindak pidana sehingga pemberian sanksi terhadap tindak pidana korupsi merupakan reaksi atas perbuatan korupsi yang dilakukan. Namun demikian dalam proses penanggulangan tindak pidana termasuk tindak pidana korupsi tidak hanya menggunakan upaya penal yang cenderung reaktif, tetapi juga upaya nonpenal dengan pendekatan preventif dengan jalan pencegahan seseorang melakukan tindak pidana. Pendekatan upaya non-penal atau preventif berporos pada penghapusan atau menghilangkan faktor-faktor potensial yang menjadi ruang terjadinya tindak pidana korupsi. Sehingga dalam penanggulangan tindak pidana korupsi di samping menggunakan upaya penal (represif) juga menggunakan upaya non-penal (preventif) guna mencegah seseorang melakukan tindak pidana korupsi.

Kebijakan Non Penal, Upaya non penal yang paling strategis adalah segala upaya untuk menjadikan masyarakat sebagai lingkungan sosial dan lingkungan hidup yang sehat (secara materiil dan immateriil) dari faktor - faktor kriminogen. Ini berarti, masyarakat dengan seluruh potensinya harus dijadikan sebagai faktor penangkal kejahatan atau faktor "antikriminogen" yang merupakan bagian integral dari keseluruhan politik kriminal. Disamping upaya - upaya non penal dapat ditempuh dengan menyehatkan masyarakat lewat kebijakan sosial dan dengan mengali berbagai potensi yang ada di dalam masyarakat itu sendiri, dapat pula upaya non penal itu digali dari berbagai sumber lainnya yang juga mempunyai potensi efek-preventif.

Pembinaan dan penggarapan kesehatan jiwa masyarakat memang tidak berarti sematamata kesehatan rohani/mental, tetapi juga kesehatan budaya dan nilai-nilau pandangan hidup masyarakat. Ini berarti penggarapan kesehatan masyarakat atau lingkungan sosial yang sehat (sebagai salah satu upaya nonpenal dalam strategi politik kriminal), tidak hanya harus berorientasi pada pendekatan religius tetapi juga berorientasi pada pendekatan identitas budaya nasional. Dilihat dari sisi upaya nonpenal ini berarti, perlu digali, dikembangkan dan dimanfaatkan seluruh potensi dukungan dan dan partisipasi masyarakat dalam upaya untuk mengektifkan dan mengembangkan "extra legal system" atau "informal and traditional system" yang ada di masyarakat. 
Optimalisasi jalur non penal sejalan dengan cita-cita bangsa dan tujuan negara, seperti yang tercantum dalam Pembukaan Undang-Undang Dasar Republik Indonesia Tahun 1945 yang memuat Pancasila (Hamdan, 1997). Segala bentuk pembangunan harus berangkat dari nilai-nilai Pancasila, karena pada hakikatnya pancasila merupakan tonggak konvergensi berbagai gagasan dan pemikiran mengenai dasar falsafah kenegaraan yang didiskusikan secara mendalam oleh para pendiri negara.

\section{SIMPULAN}

Penjatuhan terhadap terdakwa untuk mengembalikan keuangan negara sehingga pitusan tersebut tidak tepat sasaran dan sanksi yang yang diberikan Majelis hakim terhadap terdakwa tidak mengambambarkan keadilan serta ketertiban dimasyarakat, dikarenakan hukuman yang cenderung ringan serta tidak memberian efek jera terhadap pelaku tindak pidana korupsi

Upaya penanggulangan kejahatan dapat dilakukan melalui sarana "penal" dan "non penal". Upaya penanggulangan penal dalam mengatur masyarakat lewat perundang-undangan merupakan wujud suatu langkah kebijakan (policy). Upaya penanggulangan kejahatan dengan hukum pidana (sarana penal) lebih menitik beratkan pada sifat "Represive" Penindasan/pemberantasan/penumpasan), setelah kejahatan atau tindak pidana terjadi. Penanggulangan korupsi dapat dilakukan dengan cara menyerahkan kasus tindak pidana korupsi yang terjadi kepada pihak penegak hukum dalam hal ini, polisi, jaksa, dan KPK untuk diproses sesuai dengan ketentuan hukum yang berlaku. Dimana hukuman atau sanksi pidana yang dijatuhkan kepada pelaku diharapkan dapat memberikan efek jerah kepada pelaku sesuai dengan tujuan pemidanaan.

\section{DAFTAR PUSTAKA}

Bakhri, S. (2009). Pidana Denda dan Korupsi, Yogyakarta: Total Media.

Ediwarman. (2015). Monogrof Metodologi Penelitian Hukum. Medan: PT. Sofmedia

Erwin, M. (2012). Filsafat Hukum Refleksi Kritis Terhadap Hukum,Jakarta: Raja Grafindo Persada, Jakarta.

Girsang, J. (2012). Penyalahgunaan Kekuasaan Aparat Penegak Hukum Dalam Penanganan Tindak Pidana Korupsi. Jakarta: JG Publishing,

Hamdan, M. (2010). Hukuman dan Pengecualian Hukuman Menurut KUHP dan KUHAP, USU press, Medan,

Harahap, M.I.M. (2018). Analisis Yuridis Tindak Pidana Korupsi dengan Menggunakan Jabatan (Studi Putusan No. 296/Pid.B/2010/PN.Mdn). Journal of Education, Humaniora and Social Sciences (JEHSS). 1 (1): 1-8.

Hidayat, S. (2017). Tinjauan Yuridis Kewenangan Komisi Pemberantasan Korupsi Melakukan Penyidikan Penggabungan Perkara Tindak Pidana Korupsi dan Pencucian Uang, Halu Oleo Law Review (HOLREV), Vol 1, Issue 2017 , http://ojs.uho.ac.id/index.php/holrev/article/view/3641/3135, diakses pada tanggal 20 Juni 2020

Ibrahim. K.I. (1976). Pengantar hukum tata Negara Indonesia. Jakarta: PT Sastra Hudaya

Lubis, F.H., dan Marlina, (2010), Penegakan Hukum dalam Tindak Pidana Korupsi Pengadaan Barang dan Jasa (Studi pada Pengadilan Negeri Kuala Simpang), Mercatoria, 3 (2): 88-101

Nawawi, B.A. (2010). Bunga Rampai Kebijakan Hukum Pidana, Bandung: PT. Citra Aditya Bakti.

Prasetyo, T. (2014). Filsafat Teori dan Ilmu Hukum, Jakarta: Raja GrafindoPersada

Sembiring, F.K.J., dan Ediwarman, (2011), Kajian Hukum Penyalahgunaan Wewenang Oleh Kuasa Pengguna Anggaran (KPA) Dan Pejabat Pembuat Komitmen (PPK) dalam Pengadaan Barang Dan Jasa, (Studi Kasus Pemerintah Kota Binjai), Mercatoria, 4 (1): 23-32

Sihaloho, E., Mubarak, R. \& Munthe, R. (2020). Tindak Pidana Penggelapan Dalam Jabatan Dilakukan Oleh Sales Executive Hotel The Hill Sibolangit Medan (Studi Kasus Putusan Nomor : 1170/Pid.B/2016/PN. Mdn). JUNCTO, 2(1) 2020: 24-32

Syamsuddin, A. (2011). Tindak Pidana Khusus. Jakarta: Sinar Grafika 